\title{
Development of Cost Correlations for the Economic Assessment of Power Plant Equipment
}

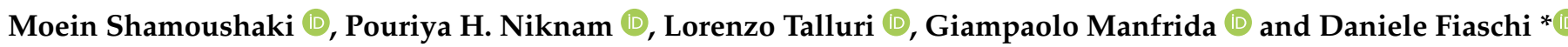 \\ Department of Industrial Engineering, University of Florence, 50134 Firenze, Italy; \\ moein.shamoushaki@unifi.it (M.S.); pouriya.niknam@unifi.it (P.H.N.); lorenzo.talluri@unifi.it (L.T.); \\ giampaolo.manfrida@unifi.it (G.M.) \\ * Correspondence: daniele.fiaschi@unifi.it
}

Citation: Shamoushaki, M.; Niknam, P.H.; Talluri, L.; Manfrida, G.; Fiaschi, D. Development of Cost Correlations for the Economic Assessment of Power Plant Equipment. Energies 2021, 14, 2665. https://doi.org/ $10.3390 /$ en 14092665

Academic Editor: Ron Zevenhoven

Received: 17 March 2021

Accepted: 28 April 2021

Published: 6 May 2021

Publisher's Note: MDPI stays neutral with regard to jurisdictional claims in published maps and institutional affiliations.

Copyright: (c) 2021 by the authors. Licensee MDPI, Basel, Switzerland. This article is an open access article distributed under the terms and conditions of the Creative Commons Attribution (CC BY) license (https:// creativecommons.org/licenses/by/ $4.0 /)$.
Abstract: A comprehensive cost correlation analysis was conducted based on available cost correlations, and new equipment cost correlation models were proposed based on QUE\$TOR modeling. Cost correlations for various types of equipment such as pumps, compressors, heat exchangers, air coolers, and pressure vessels were generated on the basis of extracted cost data. The models were derived on the basis of robust multivariable regression with the aim of minimizing the residuals by using the genetic algorithm. The proposed compressor models for both centrifugal and reciprocating types showed that the Turton cost estimation for carbon steel compressor and Matche's and Mhhe's data were compatible with the generated model. According to the results, the cost trend in the Turton correlation for carbon steel had a somewhat lower estimation than these correlations. Further, the cost trend of the Turton correlation for carbon steel pressure vessels was close to the presented model trend for both bullet and sphere types. The Turton cost trend for U-tube shell-and-tube heat exchangers with carbon steel shell and stainless steel tube was close to the proposed heat exchanger model. Furthermore, the Turton cost trend for the flat-plate heat exchanger using carbon steel was similar to the proposed model with a slight difference.

Keywords: cost correlation; power plant equipment; economic analysis

\section{Introduction}

The increasing demand for energy in many countries in recent years has fueled growth in the construction of new power plants based on conventional fuels and renewable energies. Global energy demand will rise 1.4 times, from 19,562 TWh in 2012 to 26,761 TWh by 2025 , principally in the developing countries [1]. By 2025, it is expected that world power capacity will grow by a factor of 1.4, from $6117 \mathrm{GW}$ in 2014 to $8370 \mathrm{GW}$ to meet this growth in demand. Developing countries are expected to account for about $70 \%$ of this capacity enhancement [1].

In the recent decade, many researchers have turned particular attention to the economic assessment of various energy systems. The zonal and nodal models have been applied to evaluate the energy market. To improve and develop models based on ecological and social challenges, some suggestions have been presented by Borowski [2] to improve zonal and nodal models that may hold promise as new models for the functioning of the electricity market in Europe in the near future. Poyrazoglu [3] applied three clustering methods to pricing zone detection for an electricity market in a Turkey case study. However, a more accurate estimation of equipment costs is essential to power plants' exergo-economic analysis, as those costs have direct and influential impacts on final economic results. This importance can even affect project feasibility. To calculate power plant equipment costs, some graphs and correlations in references are available; however, most are not recent, affecting the economic analysis. Moreover, manufacturers and companies rarely share their product costs; these reasons make the economic analysis 
more challenging for researchers. Applicable cost estimations have a significant impact on the profitability of a project and the technical solutions.

Capital cost estimations for a power plant are a significant element in construction decisions. In the design step, it is hard to evaluate the exact value of equipment and capital costs. There may be some scatter cost value for each unit of equipment mainly because of differences in the manufacturing process, material quality, applied technologies, the local tax, relevant expenses, etc. Material type can directly affect equipment costs, as stainless steel is around four times more expensive than steel based on MEPS International information [4].

Other researchers' economic analyses show that different approaches have been applied to the investigation of power plant investment expenses. Many researchers have used cost correlations to evaluate the equipment costs and then evaluate power plant total costs according to the calculated equipment costs. Some researchers apply the thermoeconomic approach to evaluate energy systems such as combinations of the geothermal, Organic Rankine cycle (ORC), and solar technologies [5-7]. They have combined exergy and economic concepts and used the exergo-economic approach to assess certain energy cycles such as the geothermal and ORC combined cycle [8,9], gas turbine (GT) cycle [10,11], combined solid oxide fuel cell (SOFC) and GT cycle [12,13], and refrigeration cycle [14] from both the technical and economic points of view. The application of various cost estimation methods leads to different results and can affect project arrangements.

Statistical approaches can rely on correlations or alternative methods to connect equipment features to costs. Other researchers apply a regression approach or optimization methods to obtain the best cost estimation tools $[15,16]$. The parametric cost model related to statistical methods and criteria can be applied to determine the casual links and correlate equipment costs to develop a function with one or more dependent variables [17].

Williams [18] estimated heat exchanger costs by comparing equipment pieces of the same model. Pikulik and Diaz [19] proposed a heat exchanger cost estimation approach based on diameter, type, and nuzzle size. Purohit [20] generated a complex cost model for heat exchanger cost estimation based on many factors such as shell inner diameter, material, type, pressure, number of tube passes, tube outer diameter, tube pitch, etc. Vatavuk [21] developed a model according to 1995 data on heat exchanger area to calculate the heat exchanger costs. Wang [22] carried out a computer simulation study to derive factor-based cost correlations for a given project. According to the ICARUS process evaluator, Loh et al. [23] presented a report about the cost curves for various equipment. Their proposed purchasing equipment cost estimation was based on the capacity variable. Taal et al. [24] provided a summary of some cost estimation methods for heat exchanger equipment in the industry.

Max et al. [25] performed equipment sizing and cost estimations for process equipment based on computer aided design and optimization. They considered 10 different methods in cost evaluation. Kim et al. [26] offered an applicable cost estimating model based on the hybrid concept for large building projects comprising multiple mixed-use buildings. Yang [27] proposed a generic method to combine correlations between cost factors within the cost estimation process. The presented method checks correlation feasibility first to see if it needs any adjustment or not. Turton et al. [28] proposed cost correlations of various chemical process devices based on different equipment types, materials, and pressure ranges. Caputo and Pelagagge [29] compared parametric function and artificial neural networks to calculate the cost of large and complex-shaped pressure vessels. Ogayar and Vidal [30] developed a series of correlations to estimate the cost of a small hydro-power plant's electro-mechanical equipment using basic parameters such as power and head.

Kim, K.J., and Kim, K. [31] presented a primary cost estimation model using genetic algorithm (GA) and case-based reasoning (CBR). Feng and Rangaiah [32] compared five capital cost estimation programs for some equipment. They evaluated seven case studies related to petroleum refining, petrochemical, and biopharmaceutical processes. Towler and Sinnott [33] generated an exponential correlation form to estimate purchasing equipment 
costs. Ereev and Patel [34] extended a methodology to the economic evaluation of total manufacturing production expenses by applying factors according to equipment purchase costs. Gunduz and Sahin [35] expanded two cost estimation models to evaluate hydroelectric power plant project costs by applying neural networks and multiple regression assessment in the early project stages. Symister [36] carried out capital cost estimations for chemical processing using Aspen capital cost estimator for several equipment types in his thesis. Caputo et al. [37] expanded an analytical-generative cost estimation procedure by developing a mathematical model for shell and tube heat exchangers. Luyben [38] provided a simple method to estimate compressor costs using Aspen. However, he did not apply an optimization method. Malhan and Mittal [39] applied a polynomial regression model base to generate cost correlations for the major components in micro hydro power plants. Shamoushaki et al. [40] proposed well drilling cost models for different regions. They applied robust multivariable regression to minimize the residuals. Islam et al. [41] employed an integrated fuzzy set theory and fuzzy Bayesian belief network model to risk-induced contingency cost modeling for power plant projects.

In this study, the cost analysis of the main equipment in a power plant was evaluated by extracting cost data from QUE\$TOR software based on a 2020 database [42]. The considered equipment included the pump, compressor, heat exchanger, air cooler, and pressure vessel. The process modeling was performed in QUE\$TOR, and by changing the main operational parameters of the system and equipment, relevant cost data were extracted. The curve multivariable robust regression was applied to develop equipment cost correlations comparable with data in the literature. We endeavored to generate correlations that showed the best compatibility with available data. A comprehensive cost correlation evaluation was performed on the basis of correlations presented in different research papers and references. The most reliable cost correlations were determined by comparing the proposed models with other cost correlations and data. These cost results were based on the 2020 database for the QUE\$TOR software, which suggests that they are very reliable for use by researchers and stakeholders and can help operators and investors with their decisions and estimates. This study sought to fill the gap in equipment cost estimation with these updated models.

\section{Methodology and Curve Fitting}

The best-fitted models were generated using curve fitting to compare with the available database. The goal of the curve fitting process was to find a function $\left(f\left(x_{i}, y_{i}\right)\right)$ based on the input data, in which $i$ is the data number. The most compatible and reliable fit was derived by minimizing the objective function defined in terms of the distance between the derived correlation and variables [43]. Generally, some innovative solutions such as the industry 4.0 paradigm, machine learning, etc., are used to develop more profitable projects in the energy market [44]. The cost data were collected based on the equipment and process modeling simulation by IHS Markit QUE\$TOR software, which used a comprehensive database (updated in 2020, Q1). We sought to extract cost data by changing the main operational parameters of the equipment and evaluating their impacts on equipment cost. A general correlation form was generated for all cases as Equation (1):

$$
C=\log (x)+a \cdot(x)^{2}+b \cdot x+c
$$

In Equation (1), $a, b$, and $c$ are constant coefficients, $x$ is a dependent variable that can vary based on the equipment, and $C$ is the cost (\$). A logarithmic and non-linear equation was considered on the basis of available data and cost trends; a logarithmic form is common for equipment cost estimation [31].

Several cost correlation forms were evaluated to find the best compatibility with the available data. Different fitting approaches and types were applied and considered using the reference data. Both graphical and numerical fittings were evaluated for each case to reduce errors. The examination was performed according to the residuals and statistical factors, including the fit statistics and confidence intervals on the fitted coefficients. The 
former showed how much fitting was matched with the data, and the latter showed the exactitude of the coefficients. The main statistical parameters, such as sum of squares (SSE) (due to error) and coefficient of determination $\left(R^{2}\right)$ were considered in the cost model evaluations. Moreover, the R-square value was evaluated for each correlation, which was a statistical parameter of how close the data was to the fitted regression line. These examinations could be performed by differentiating, integrating, interpolating, or extrapolating the fitting. In the curve fitting process, based on data dissemination and points, the fitting weight was adjusted to achieve the best compatibility with the data. Some statistical parameters of cost models were introduced in Table 1 . In this table, unit A is the area of the heat exchanger.

Table 1. The statistical parameters of modeling.

\begin{tabular}{|c|c|c|c|c|c|c|}
\hline Equipment & Type & Range & $\begin{array}{l}\text { Number } \\
\text { of Data }\end{array}$ & Mean (\$) & Median (\$) & Confidence Interval (\%) \\
\hline Compressor & Centrifugal & $10-10,000(\mathrm{~kW})$ & 160 & $3.62 \times 10^{6}$ & $3.245 \times 10^{6}$ & \pm 10.5 \\
\hline Compressor & Reciprocating & $10-10,000(\mathrm{~kW})$ & 160 & $3.484 \times 10^{6}$ & $3.12 \times 10^{6}$ & \pm 10.3 \\
\hline Condenser & Air cooler & $1-3500(\mathrm{~A})$ & 200 & $7.981 \times 10^{5}$ & $2.748 \times 10^{6}$ & \pm 10.6 \\
\hline Pump & Centrifugal & 20-3500 (kW) & 140 & $6.571 \times 10^{5}$ & $6.415 \times 10^{5}$ & \pm 9.4 \\
\hline Pressure vessel & Bullet & $1-1000\left(\mathrm{~m}^{3}\right)$ & 180 & $3.607 \times 10^{5}$ & $2.865 \times 10^{5}$ & \pm 12.1 \\
\hline Pressure vessel & Sphere & $1-1000\left(\mathrm{~m}^{3}\right)$ & 180 & $4.994 \times 10^{5}$ & $3.95 \times 10^{5}$ & \pm 12.4 \\
\hline Heat exchanger & Shell \& Tube & $1-3500(\mathrm{~A})$ & 200 & $7.048 \times 10^{5}$ & $2.259 \times 10^{6}$ & \pm 10.2 \\
\hline Heat exchanger & Flat plate & $1-1000(\mathrm{~A})$ & 180 & $5.439 \times 10^{5}$ & $2.761 \times 10^{5}$ & \pm 9.1 \\
\hline
\end{tabular}

Considering the objective function according to Equation (2), independent error minimization was performed [45] by the genetic algorithm, which is a heuristic approach based on natural selection. It was utilized to optimize the correlations and derive the relevant coefficients [46].

$$
\text { Min : } \sum_{j=1}^{m} \sum_{i}^{n}\left(\left(x_{i, j}-x_{i, j}^{\prime}\right)^{2}\right)
$$

In this equation, $x_{i, j}$ and $x_{i, j}^{\prime}$ are calculated as reference values, respectively. There is no restriction of correlation form and coefficient number in this minimization method [45]. The upper limit of iteration was considered to be 2000. The selected population was different for each piece of equipment, and the generation was considered 300. Additionally, the mutation and crossover fraction factors were supposed to be 0.2 and 0.8 , respectively. The genetic algorithm was chosen because of its specific advantages: acceptable convergence rate, suitability for a wide variety of optimization problems, wide solution space searchability, and ease in discovering global optimums and avoiding trapping in local optimal. The genetic algorithm does not require any information about the function's structure to be optimized and uses it as a Black Box. Despite being proposed almost 50 years ago, the genetic algorithm, due to its performance, is still an exciting tool in various fields. It can be seen that this algorithm remains a handy tool in finance and economics, and particularly in forecasting the prices of various commodities [47].

After generating the cost model for each piece of equipment, other cost correlations and data based on the available correlation from different references were compared with the proposed model to find the most reliable correlations. As the costs based on various correlations reveal scattered results, finding the most fitted and general correlations to reach the exact evaluation of total plant cost is crucial. Comprehensive cost correlations were collected and are listed in Appendix A, which contains cost correlations for pumps, heat exchangers, condensers, and compressors. As the inflation rate directly impacts equipment costs, the inflation rate index should be applied in the economic assessment 
process. The Chemical Engineering Plant Cost Index (CEPCI) was applied based on the year of each equation presented to consider the current year's inflation rate. The related cost correlation based on the Turton correlations [28] was considered in the examination process. Besides these, other available cost data from other websites (Matche [48] and Mhhe [49]) and references were collected to compare with the proposed cost models. The schematic diagram of the fitted line for the centrifugal compressor is displayed in Figure 1. This graph shows that the proposed model had a good fitting with available cost data. The flowchart of cost model generation is illustrated in Figure 2. The schematic of a conventional geothermal power plant with target equipment for this study is illustrated in Figure 3.

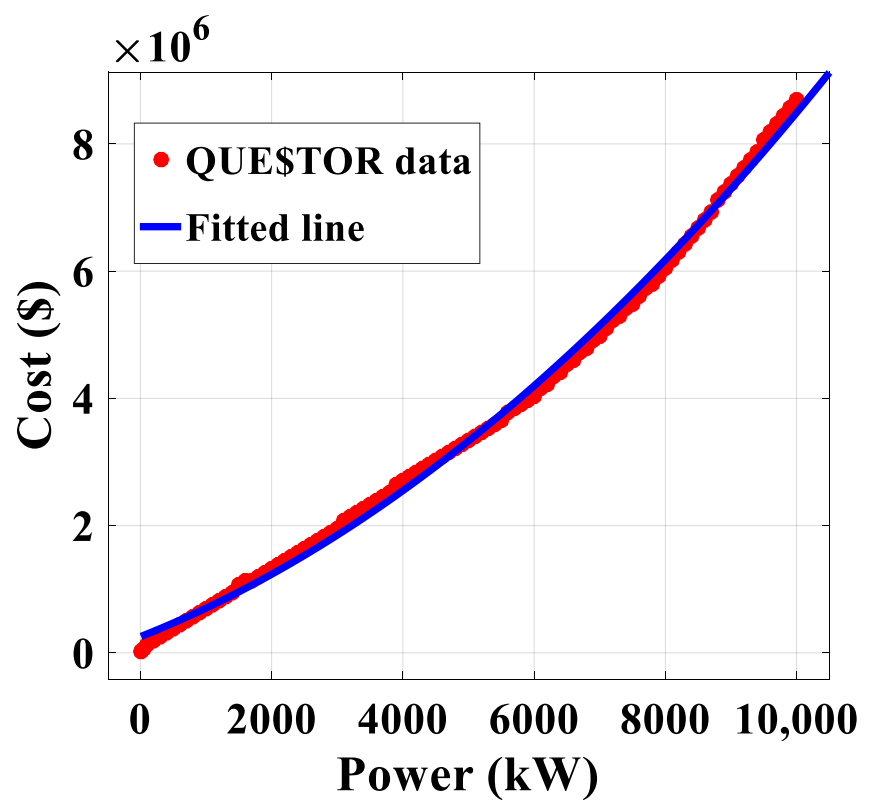

Figure 1. Fitting line for centrifugal compressor.

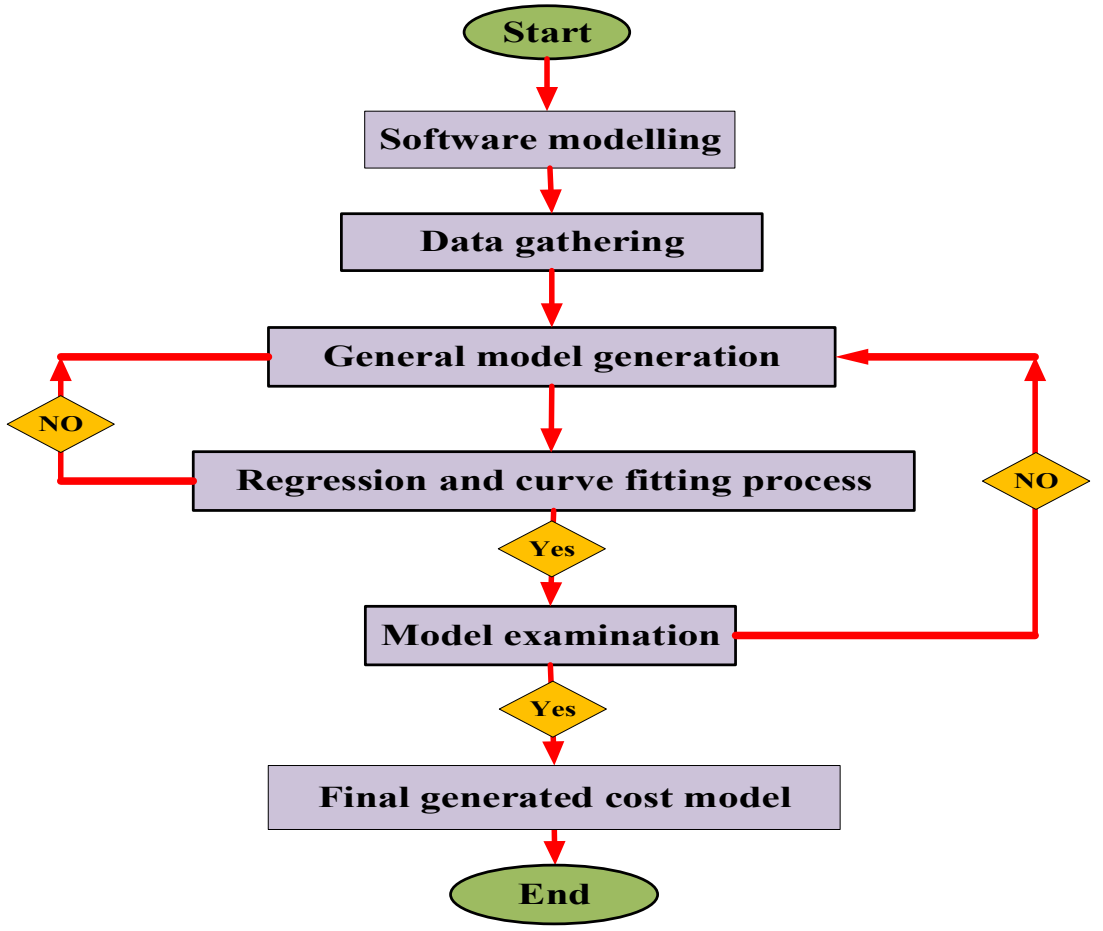

Figure 2. Flowchart of cost model generation. 


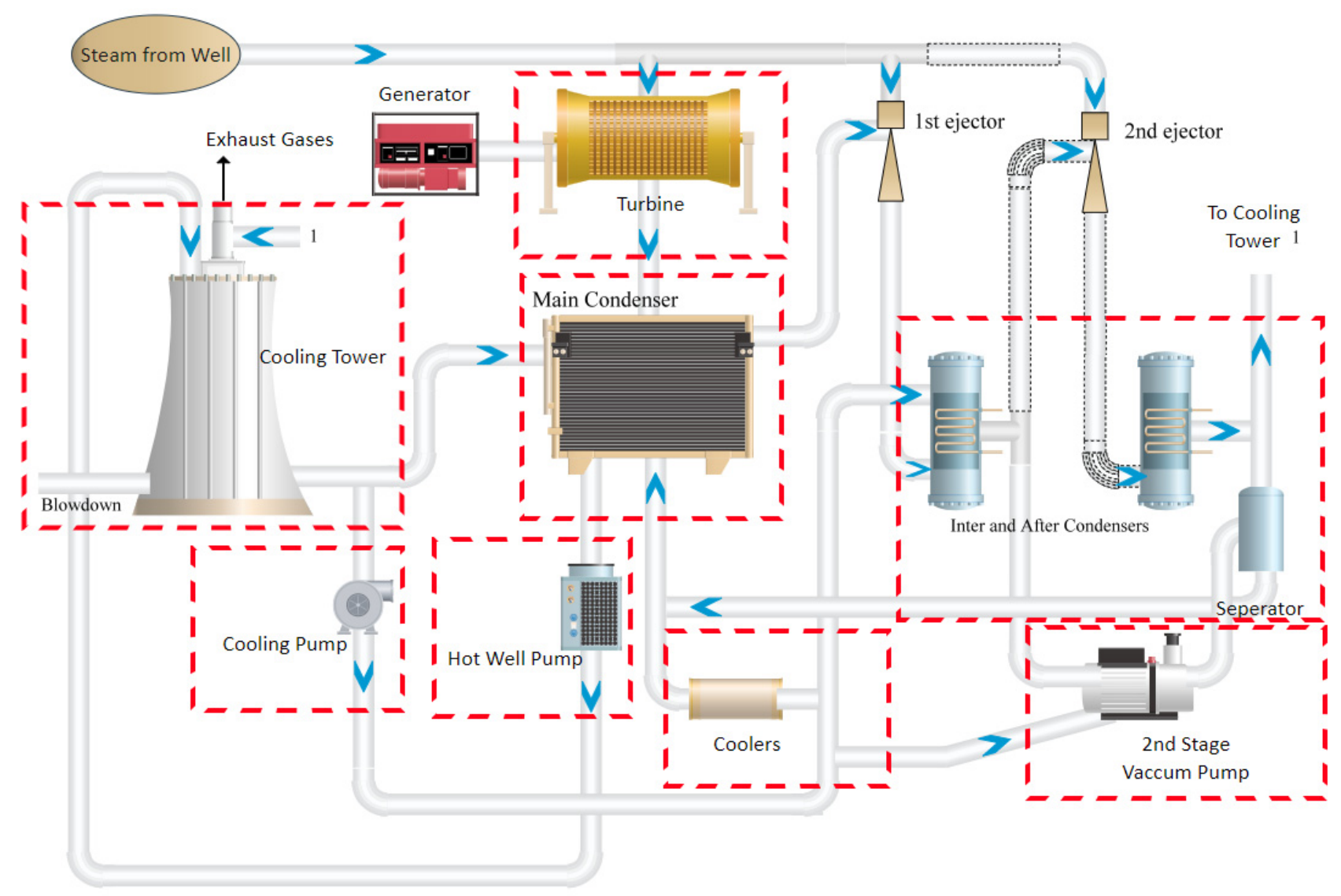

Figure 3. Scope of cost model for conventional geothermal power plant [50].

\section{Results and Discussion}

This research sought to generate equipment cost correlations according to the QUE\$TOR modeling and cost database. The reference database was related to the first quarter of 2020, and the extracted correlations were applicable to studies dedicated to future power plant economic assessments. They could help researchers and stakeholders gain a better understanding of the expenses. Comprehensive cost correlations were collected from other research papers and references to compare with the proposed models and understand their reliability. Correlations were generated based on the best compatibility with available data. Different fitting methods were applied to optimize the final results. The obtained results and cost correlations are as follows:

\subsection{Compressor}

The cost trends for centrifugal and reciprocating compressors are shown in Figures 4 and 5, respectively. In addition to the Turton cost correlation, three other cost correlations were evaluated to compare with the proposed model. Figure 4 shows that the proposed QUE\$TOR cost model was very close to the Turton, Matche, and Mhe estimations for carbon steel material, suggesting that these three cost correlations provide better cost estimations than others. The reciprocating compressor's cost trend, based on the proposed model and other cost correlations, is displayed in Figure 5. The closest cost trend to the proposed model was the Turton correlation for carbon steel material. 


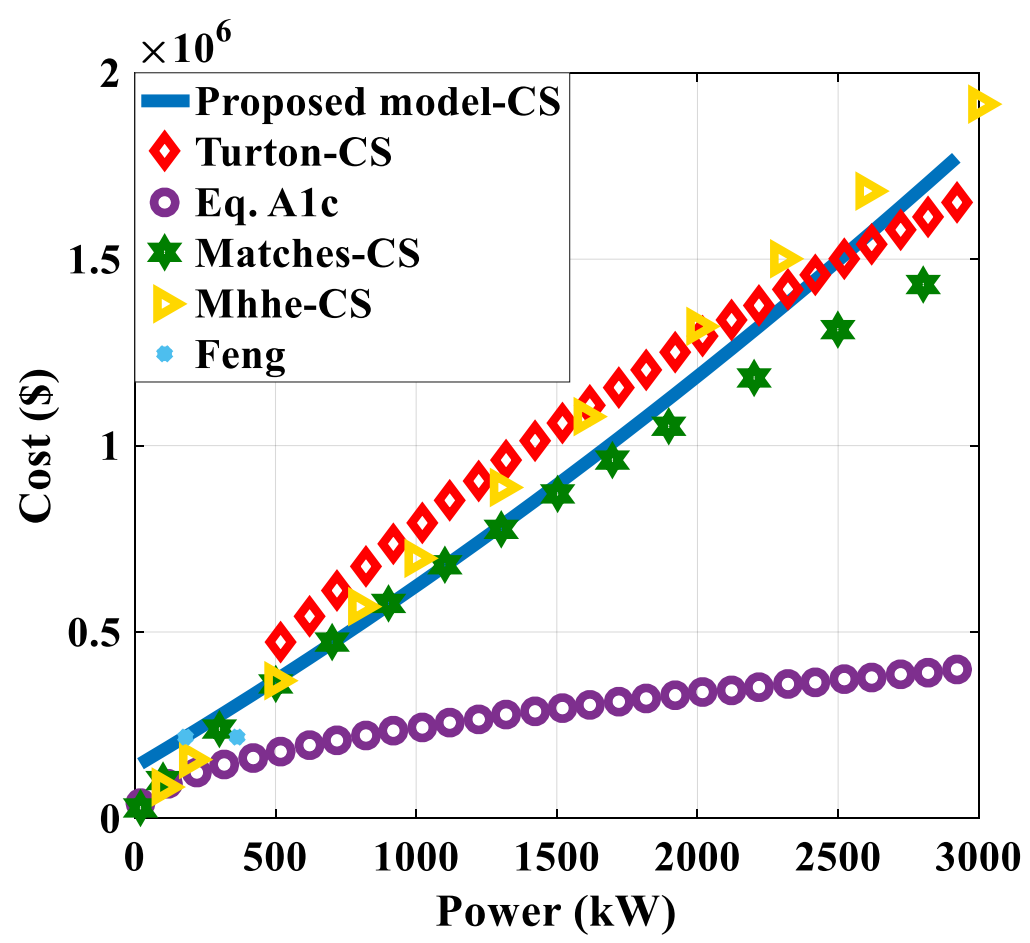

Figure 4. Compressor (centrifugal) cost against power $[28,32,48,49,51]$.

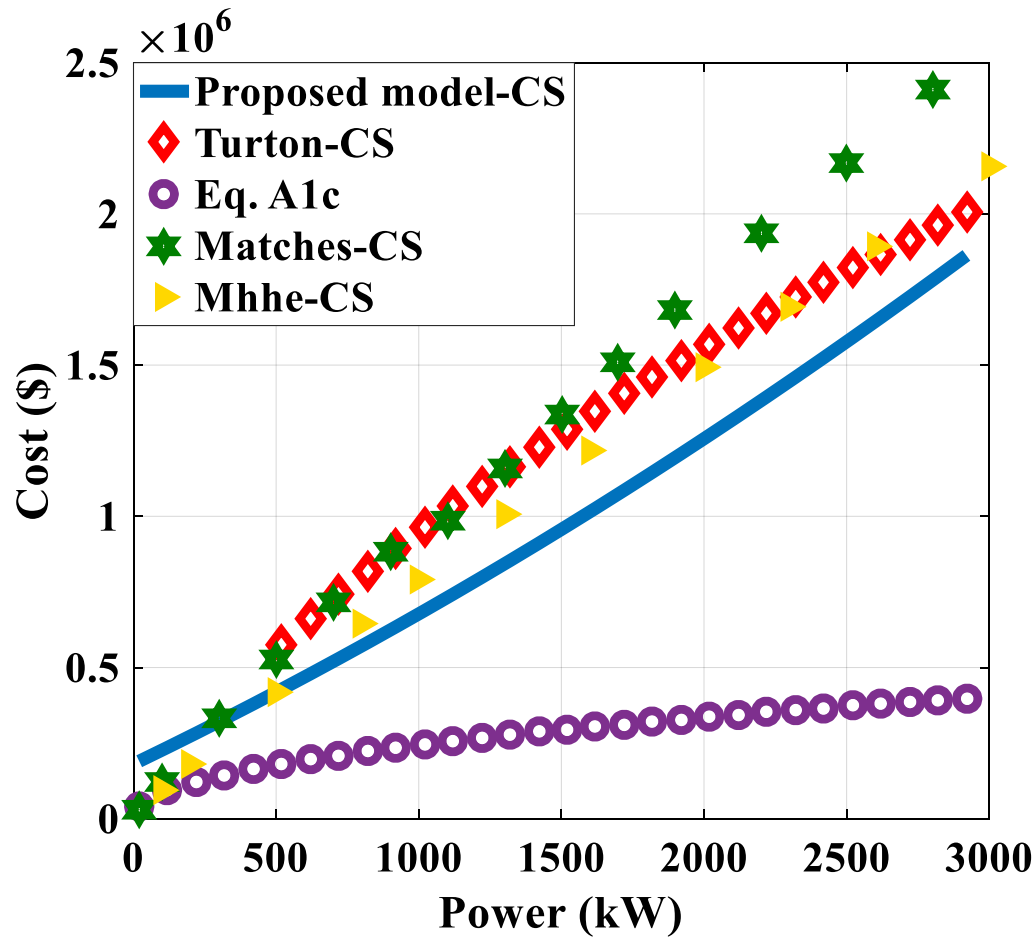

Figure 5. Compressor (reciprocating) cost against power [28,48,49,51].

Moreover, the cost prediction based on Mhhe's and Matche's data was approached that of the proposed QUE\$TOR model. Also, the Feng and Rangaiah [32] presented cost data for low-power compressors fitted with the proposed model. The general form of compressor cost correlation is illustrated in Equation (3), and the coefficients for both compressor types are listed in Table 2.

$$
C=\log \left(\dot{W}_{\text {Comp }}\right)+a \cdot\left(\dot{W}_{\text {Comp }}\right)^{2}+b \cdot \dot{W}_{\text {Comp }}+c
$$


Table 2. The coefficients of Equation (2) for both compressor types.

\begin{tabular}{ccccc}
\hline Compressor Type & $\boldsymbol{a}$ & $\boldsymbol{b}$ & $\boldsymbol{c}$ & $\boldsymbol{R}^{2}$ \\
\hline Centrifugal & 0.03867 & 446.7 & $1.378 \times 10^{5}$ & 0.99 \\
\hline Reciprocating & 0.04147 & 454.8 & $1.81 \times 10^{5}$ & 0.96 \\
\hline
\end{tabular}

In this equation, $\dot{W}_{\text {Comp }}$ is compressor power $(\mathrm{kW})$ and $C$ is the cost (\$).

\subsection{Air Cooler Condenser}

Figure 6 illustrates the air cooler condenser cost trend for the proposed QUE\$TOR model and other cost correlations. It is clear from this graph that cost trends of Equations (A2e) and (A3f) are compatible with the proposed model; however, the Turton correlation for carbon steel was lower than these correlations. Furthermore, Matche's cost data for air coolers based on different materials are shown in Figure 7. As these costs include stainless steel, it can be seen that they are higher than the proposed model, which is related to carbon steel. The general form of cost correlation for an air cooler is presented in Equation (4), and the relevant correlations are listed in Table 3.

$$
C=\log (A)+a \cdot(A)^{2}+b \cdot A+c
$$

where $A$ is compressor power $\left(\mathrm{m}^{2}\right)$ and $C$ is the cost (\$).

Table 3. The coefficients of Equation (3) for air coolers.

\begin{tabular}{ccccc}
\hline Equipment & $\boldsymbol{a}$ & $\boldsymbol{b}$ & $\boldsymbol{c}$ & $\boldsymbol{R}^{2}$ \\
\hline Air Cooler & 0.01764 & 617.4 & $3.31 \times 10^{4}$ & 0.95 \\
\hline
\end{tabular}

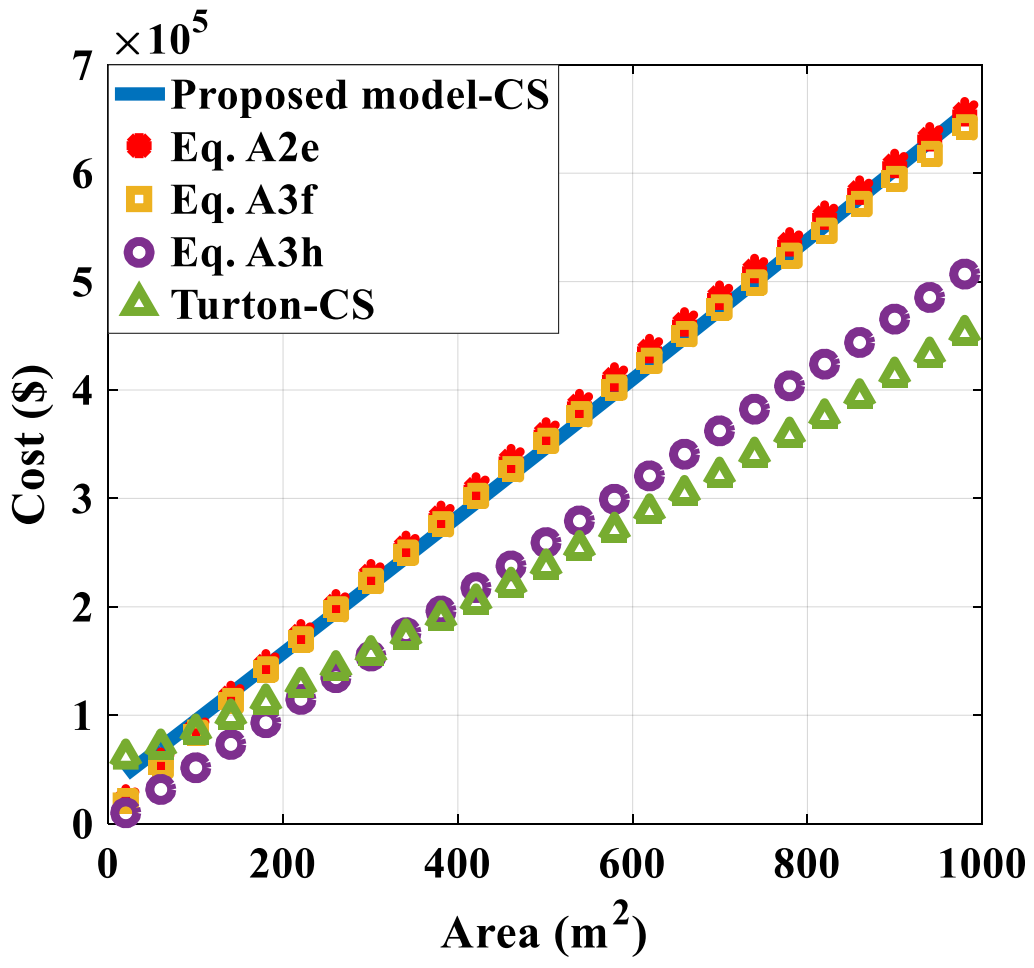

Figure 6. Air cooler cost against area [28,52-54]. 


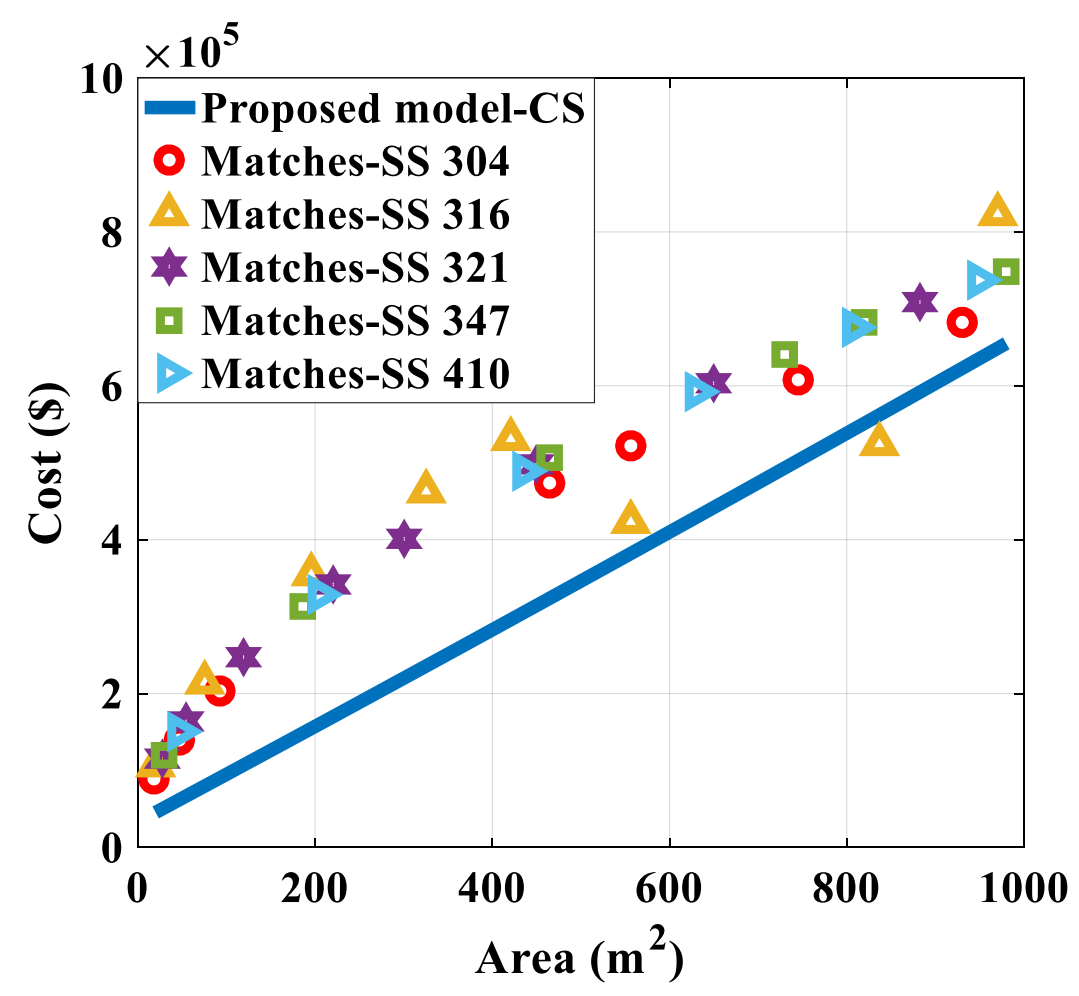

Figure 7. Air cooler cost against area [48].

\subsection{Pump}

Figure 8 presents cost trends for centrifugal pumps according to the proposed QUE\$TOR model and other cost correlations. Besides the Turton correlations, 14 other pump cost correlations were considered to compare the results with the proposed model. It can be seen that the cost estimation of Equation A4.14 and Turton correlations for carbon steel centrifugal pumps and positive displacement were close to the proposed model. The other cost correlations that are not listed in this graph had an unfitted trend with the presented model. Additionally, the cost data presented by Feng and Rangaiah [32] for low power pumps were close to the proposed model. The general cost correlation form of pump and corresponding coefficients are presented in Equation (5) and Table 4, respectively.

$$
C=\log \left(\dot{W}_{P}\right)+a \cdot\left(\dot{W}_{P}\right)^{2}+b \cdot \dot{W}_{P}+c
$$

Table 4. The coefficients of Equation (4) for centrifugal pumps.

\begin{tabular}{ccccc}
\hline Equipment & $\boldsymbol{a}$ & $\boldsymbol{b}$ & $\boldsymbol{c}$ & $\boldsymbol{R}^{2}$ \\
\hline Pump & -0.03195 & 467.2 & $2.048 \times 10^{4}$ & 0.97 \\
\hline
\end{tabular}

In this equation, $\dot{W}_{P}$ is compressor power $(\mathrm{kW})$ and $C$ is the cost $(\$)$.

\subsection{Pressure Vessel}

The pressure vessel cost trend for the proposed QUE\$TOR model and other cost correlations are displayed in Figure 9. As can be seen, the cost trend of the Turton correlation for carbon steel pressure vessels was close to the presented model trend for both bullet and sphere types. The Feng and Rangaiah [32] presented cost data for pressure vessels was acceptably close to the proposed model. The general form of pressure vessel cost correlation based on volume is presented in Equation (6). Also, the relevant coefficients are presented in Table 5.

$$
C=\log (V)+a \cdot(V)^{2}+b \cdot V+c
$$




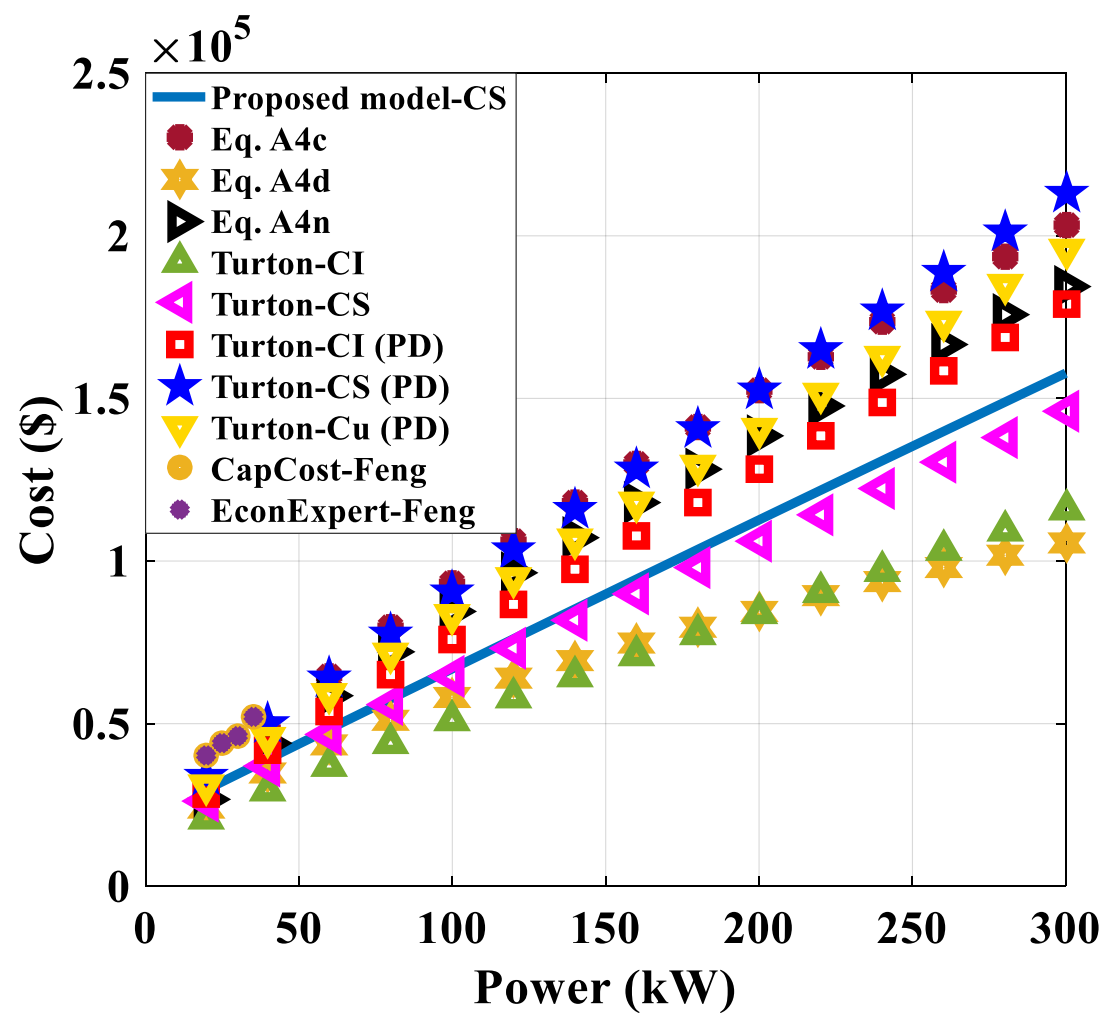

Figure 8. Centrifugal pump cost against power [28,32,55-57].

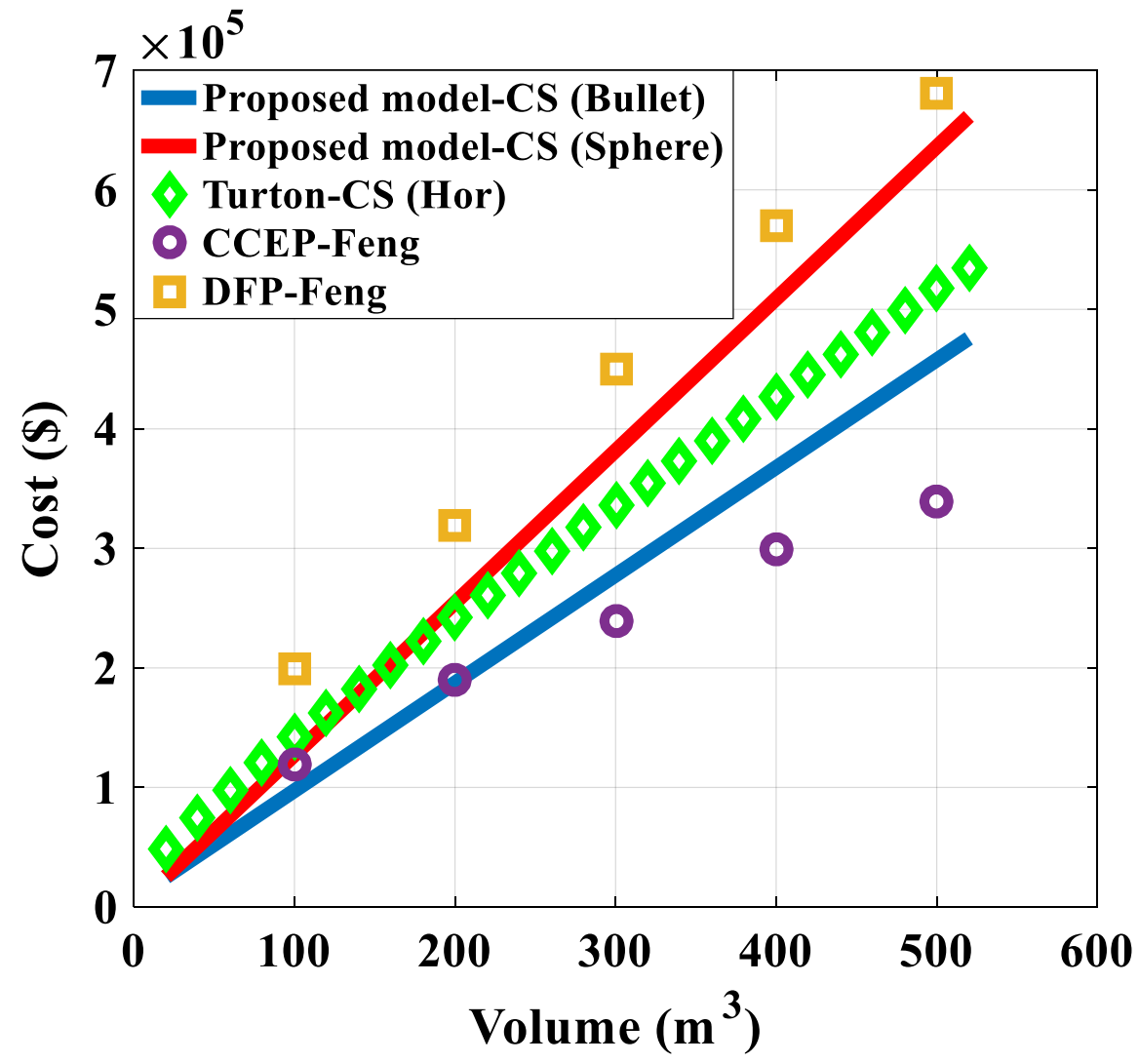

Figure 9. Pressure vessel cost against capacity $[28,32]$. 
Table 5. The coefficients of Equation (5) for pressure vessels.

\begin{tabular}{ccccc}
\hline Vessel Type & $\boldsymbol{a}$ & $\boldsymbol{b}$ & $\boldsymbol{c}$ & $\boldsymbol{R}^{2}$ \\
\hline Bullet & -0.002745 & 902.6 & 7061 & 0.99 \\
\hline Sphere & -0.001613 & 1273 & -68.46 & 0.98 \\
\hline
\end{tabular}

Here, $V$ is compressor power $\left(\mathrm{m}^{3}\right)$ and $C$ is the cost $(\$)$.

\subsection{Heat Exchanger (Shell-and-Tube, Flat Plate)}

Figure 10 shows the cost trends for shell-and-tube heat exchangers according to the proposed model and other cost correlations. In addition to the Turton, 33 other heat exchanger cost correlations (presented in Appendix A) were considered in this study. Among these cost correlations, only Equation (A2e) had a trend close to that of the proposed model. As the extracted model was based on a carbon steel shell and stainless steel tube, it can be seen that the Turton cost trend for a U-tube shell-and-tube heat exchanger with carbon steel shell and stainless steel tube was close to the trend obtained with the QUE\$TOR cost model. Figure 11 shows the proposed model and Matche's data and the Feng and Rangaiah [32] data for a shell-and-tube heat exchanger. Feng and Rangaiah [32] presented cost data were related to different programs such as Detailed Factorial Method (DFP), Capital Cost Estimation Program (CCEP), Aspen, CapCost, and Econexpert. The flat plate heat exchanger's cost trend based on the generated QUE\$TOR model and the Turton correlation are displayed in Figure 12. As can be observed, the Turton cost trend for a flat-plate heat exchanger using carbon steel was similar to that of the proposed model, albeit somewhat different. The general form of the generated cost correlation for the heat exchanger is the same for the air cooler based on the area heat exchanger. The corresponding coefficients of cost correlations for both heat exchanger types are presented in Table 6.

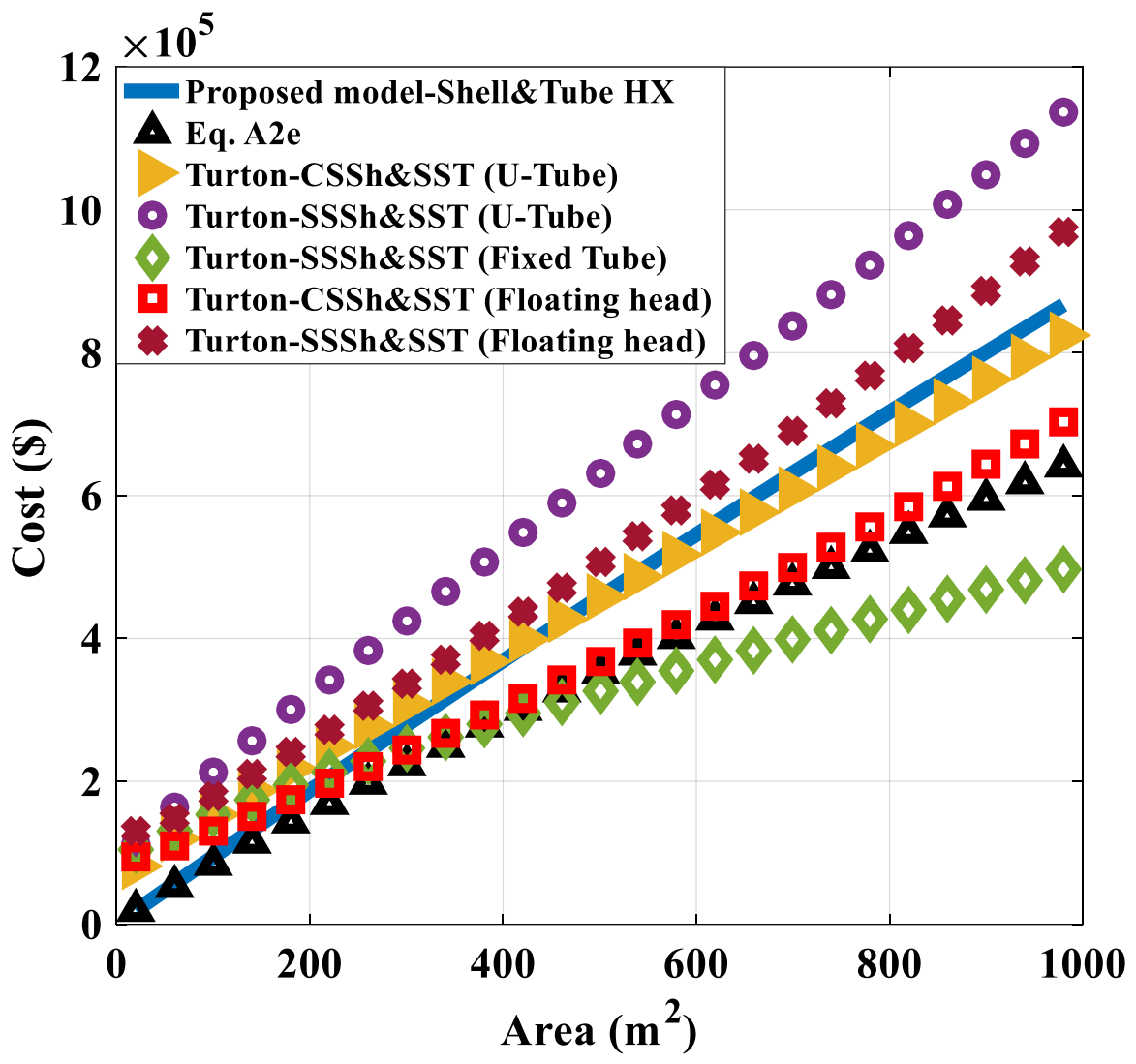

Figure 10. Shell-and-tube heat exchanger cost against the area $[28,52]$. 


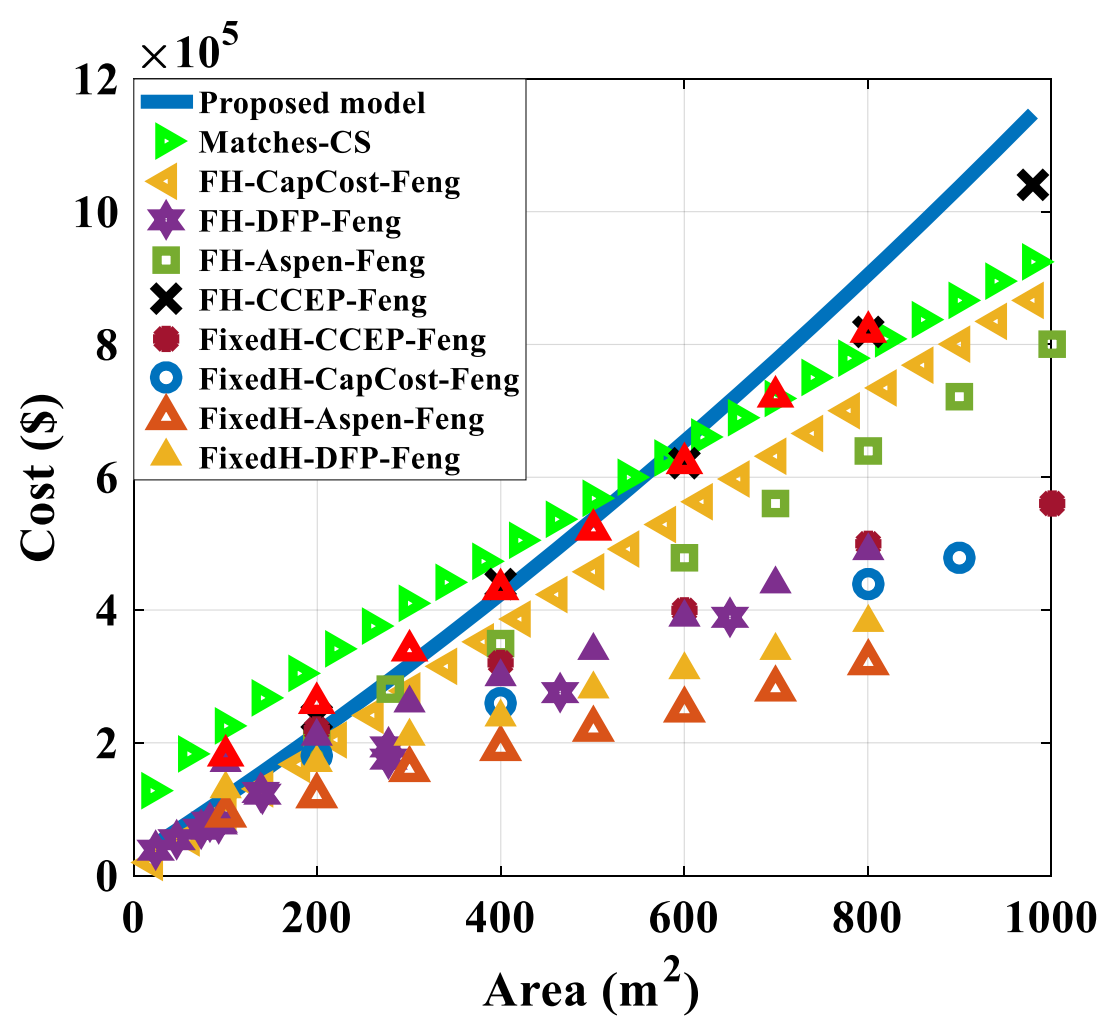

Figure 11. Shell-and-tube heat exchanger cost against the area [32,48].

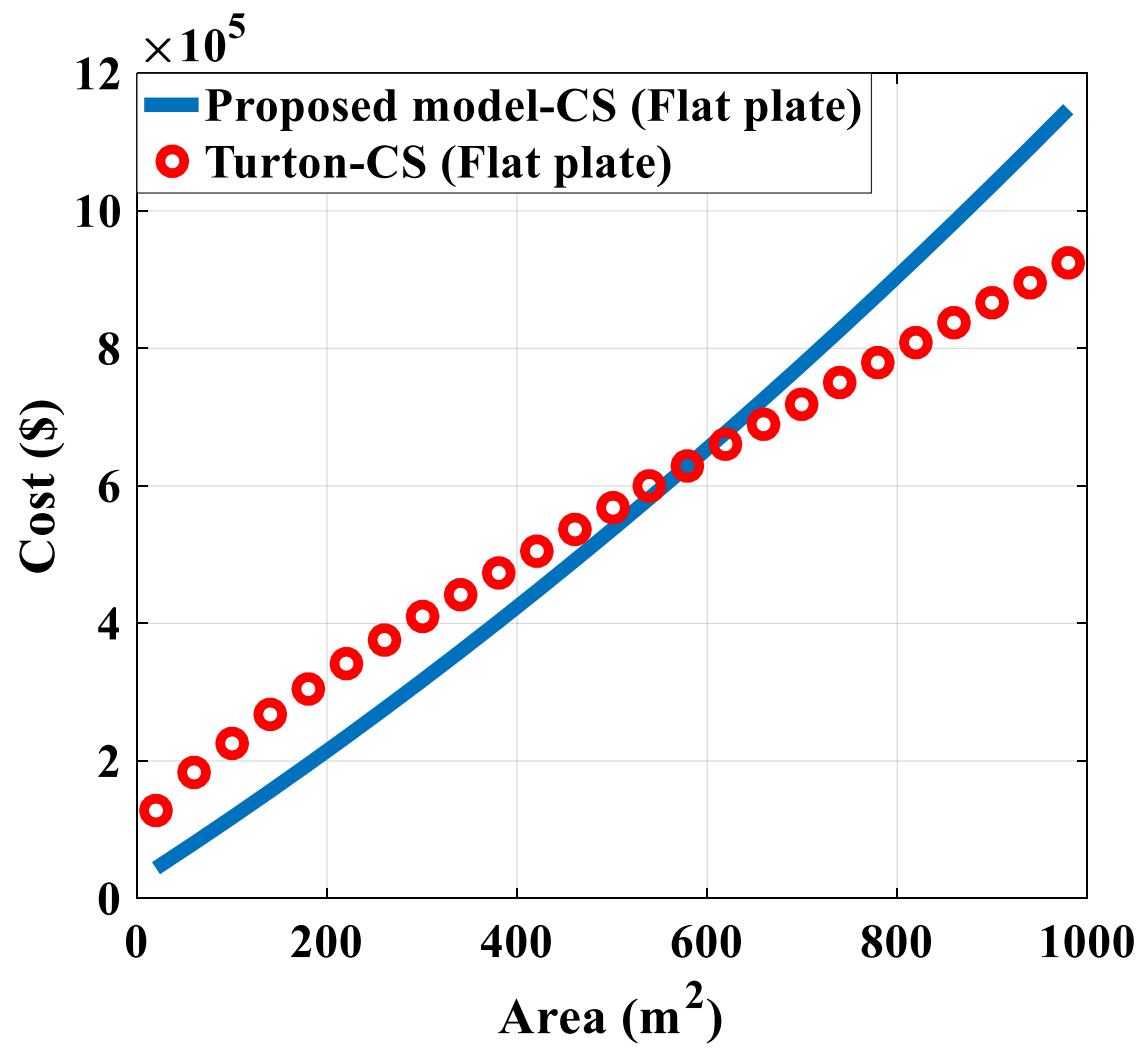

Figure 12. Flat plate heat exchanger cost against area [28]. 
Table 6. The coefficients of Equation (3) for heat exchangers.

\begin{tabular}{ccccc}
\hline $\begin{array}{c}\text { Heat Exchanger } \\
\text { Type }\end{array}$ & $\boldsymbol{a}$ & $\boldsymbol{b}$ & $\boldsymbol{c}$ & $\boldsymbol{R}^{2}$ \\
\hline Shell \& Tube & -0.06395 & 947.2 & 227.9 & 0.98 \\
\hline Flat plate & 0.2581 & 891.7 & $2.605 \times 10^{4}$ & 0.96 \\
\hline
\end{tabular}

The fitting approach in this study was developed by minimizing the residuals to improve the obtained results and equation accuracy. The genetic algorithm was applied to achieve this goal. Some researchers have not applied the optimization method to the cost estimation process, as that could increase the uncertainties and errors of the final models. Other researchers have applied the genetic algorithm optimization approach to calculate the cost correlations with different elements, and all showed promising results compared with other algorithms. However, few research studies have shown consideration for the generation of power plant equipment cost correlations. That is because gathering the equipment cost data is difficult, and the data resources are limited. On the other hand, as other, available studies noted several years ago, these updated and proposed correlations could help researchers and stakeholders to better predict equipment costs.

The proposed models in this study have several advantages compared with earlier models. First, the generated models are related to the 2020 database, which means they are the most recently updated models for the estimation of power plant purchasing costs. These models are suitable for various power cycle cost estimations. Most significantly, the benefit of this work is in applying optimization methods after generating the cost correlations and relevant coefficients. The optimization is done by a genetic algorithm to reduce errors and optimize the cost models based on available data. Other researchers' results have shown that applying optimization methods can reduce the uncertainties of cost estimation. Other studies mainly consider one or two types of equipment when generating their cost correlations; however, in the present work, the most significant equipment cost models are generated in a research package.

\section{Conclusions}

In this study, the power plant's main equipment costs were considered using QUE\$TOR software, which is linked to cost data for 2020. The considered types of equipment were the pump, compressor, heat exchanger, air cooler, and pressure vessel. The cost data were extracted by modeling in QUE\$TOR and changing the main parameters of the system. After data gathering, the equipment cost correlations based on the available data were generated by applying a robust surface modeling approach. The available cost correlations from different research papers and references were collected to compare the results with the proposed QUE\$TOR model and find better and more reliable correlations. A general form of correlation was generated for each piece of equipment based on its primary dependent variable, and relevant coefficients were calculated based on the best compatibility with available data. Results showed that the Turton correlation and Matche's and Mhhe's cost data for both centrifugal and reciprocating compressors were compatible with the proposed QUE\$TOR model. The proposed cost model related to the air cooler illustrated that Equations (A2e) and (A3f) (presented in Appendix A) had a better fitting than others. Conversely, Equation (A3h) and Turton's cost evaluations for carbon steel were a bit lower than that obtained with the proposed model. Other cost correlations had scattered and unfitted cost trends compared with that of the proposed model. The proposed carbon steel centrifugal pump model showed that Equation (A4n) and Turton carbon steel centrifugal pump cost trends had close results and could calculate reliable cost estimates. Cost correlations for pressure vessels were presented for two different types (bullet and sphere) using carbon steel material. According to the results, the Turton estimation of the pressure vessel for carbon steel and Feng and Rangaiah presented cost had close trends with the proposed models. Based on the obtained results, the Turton cost estimation for shell-and-tube heat 
exchangers using carbon steel shell and stainless steel tube had good compatibility with the proposed model.

Moreover, the flat plate cost prediction by Turton for carbon steel flat-plate heat exchanger had a somewhat different trend. The generated cost correlations had high compatibility (about 95\%) with the cost data for all evaluated equipment. These correlations were applicable to a wide range of dependent variables (power for pump and compressor, area for heat exchangers, and capacity for pressure vessel). The proposed cost models for all considered equipment are reliable for the evaluation of equipment costs and could help researchers and stakeholders gain a better understanding of the expenses, as these data are updated based on the 2020 database.

Author Contributions: Conceptualization, M.S. and P.H.N.; methodology, M.S.; software, M.S. and P.H.N.; validation, P.H.N. and L.T.; formal analysis, M.S.; investigation, M.S.; data curation, P.H.N. and L.T.; writing—original draft preparation, M.S.; writing—review and editing, P.H.N. and L.T.; supervision, G.M. and D.F.; project administration, G.M. and D.F. All authors have read and agreed to the published version of the manuscript.

Funding: This research received no external funding.

Conflicts of Interest: The authors declare no conflict of interest.

\section{Nomenclature}

$\begin{array}{ll}a: b, c & \text { Coefficients } \\ A & \text { Area, }\left(\mathrm{m}^{2}\right) \\ \text { CI } & \text { Cast Iron } \\ \text { CCEP } & \text { Capital Cost Estimation Program } \\ \text { DFP } & \text { Detailed Factorial Method } \\ \text { FixedH } & \text { Fixed head } \\ \text { FH } & \text { Floating head } \\ \text { Hor } & \text { Horizontal } \\ V & \text { Volume, }\left(\mathrm{m}^{3}\right) \\ \dot{W} & \text { Power, }(\mathrm{kW}) \\ Z & \text { Capital cost of components, }(\$) \\ \text { Subscripts } & \\ \text { Comp } & \text { Compressor } \\ \text { Cond } & \text { Condenser } \\ H X & \text { Heat exchanger } \\ P & \text { Pump }\end{array}$

\section{Appendix A}

Table A1. Compressor purchasing cost equations.

\begin{tabular}{ccc}
\hline NO & Equation & References \\
\hline A1a & $Z_{\text {Comp }}=91,562 \times\left(\dot{W}_{\text {Comp }} / 455\right)^{0.67}$ & {$[58]$} \\
\hline A1b & $Z_{\text {Comp }}=9624.2 \times \dot{W}_{\text {Comp }} 0.46$ & {$[59]$} \\
\hline A1c & $Z_{\text {Comp }}=10,167.5 \times \dot{W}_{\text {Comp }} 0.46$ & {$[51]$} \\
\hline
\end{tabular}


Table A2. Heat exchanger purchasing cost equations.

\begin{tabular}{|c|c|c|}
\hline NO & Equation & References \\
\hline $\mathrm{A} 2 \mathrm{a}$ & $Z_{H X}=10,000+324 \times A^{0.91}$ & {$[60]$} \\
\hline $\mathrm{A} 2 \mathrm{~b}$ & $Z_{H X}=130 \times(A / 0.093)^{0.78}$ & [58] \\
\hline $\mathrm{A} 2 \mathrm{c}$ & $Z_{H X}=16,000 \times(A / 100)^{0.6}$ & [58] \\
\hline $\mathrm{A} 2 \mathrm{~d}$ & $Z_{H X}=12,000 \times(A / 100)^{0.6}$ & {$[58,61]$} \\
\hline $\mathrm{A} 2 \mathrm{e}$ & $Z_{H X}=1397 \times A^{0.89}$ & [52] \\
\hline $\mathrm{A} 2 \mathrm{f}$ & $Z_{H X}=2143 \times A^{0.514}$ & {$[62]$} \\
\hline $\mathrm{A} 2 \mathrm{~g}$ & $Z_{H X}=2681 \times A^{0.59}$ & {$[63]$} \\
\hline $\mathrm{A} 2 \mathrm{~h}$ & $Z_{H X}=96.2 \times A$ & {$[64]$} \\
\hline $\mathrm{A} 2 \mathrm{i}$ & $Z_{H X}=34.9 \times A$ & {$[64]$} \\
\hline $\mathrm{A} 2 \mathrm{j}$ & $Z_{H X}=45.7 \times A$ & [64] \\
\hline A2k & $Z_{H X}=309.14 \times A^{0.85}$ & [65] \\
\hline A21 & $Z_{H X}=231.915+(309.143 \times A)$ & {$[66]$} \\
\hline $\mathrm{A} 2 \mathrm{~m}$ & $Z_{H X}=190+(310 \times A)$ & [67] \\
\hline $\mathrm{A} 2 \mathrm{n}$ & $Z_{H X}=588 \times A^{0.80}$ & [68] \\
\hline A2o & $Z_{H X}=7000+\left(360 \times A^{0.85}\right)$ & [69] \\
\hline $\mathrm{A} 2 \mathrm{p}$ & $Z_{H X}=1.3 \times(190+(310 \times A))$ & [70] \\
\hline $\mathrm{A} 2 \mathrm{q}$ & $Z_{H X}=3.28 \times 10^{4} \times(A / 80)^{0.68}$ & [53] \\
\hline $\mathrm{A} 2 \mathrm{r}$ & $Z_{H X}=383.5 \times A^{0.65}$ & [71] \\
\hline $\mathrm{A} 2 \mathrm{~s}$ & $Z_{H X}=8500+409 \times A^{0.85}$ & {$[54]$} \\
\hline $\mathrm{A} 2 \mathrm{t}$ & $Z_{H X}=14,000+614 \times A^{0.92}$ & [72] \\
\hline $\mathrm{A} 2 \mathrm{u}$ & $Z_{H X}=17,500+699 \times A^{0.93}$ & [72] \\
\hline $\mathrm{A} 2 \mathrm{v}$ & $Z_{H X}=885 \times A^{0.432}$ & [21] \\
\hline $\mathrm{A} 2 \mathrm{w}$ & $Z_{H X}=231 \times A^{0.639} \quad$ (flat plate) & [21] \\
\hline $\mathrm{A} 2 \mathrm{x}$ & $Z_{H X}=1391 \times A^{0.778} \quad$ (flat plate) & {$[72]$} \\
\hline $\mathrm{A} 2 \mathrm{y}$ & $Z_{H X}=635.14 \times A^{0.778} \quad$ (flat plate) & {$[72]$} \\
\hline
\end{tabular}

Table A3. Condenser purchasing cost equations.

\begin{tabular}{ccc}
\hline NO & Equation & References \\
\hline A3a & $Z_{\text {Cond }}=8000 \times(A / 100)^{0.60}$ & {$[55,58,61]$} \\
\hline A3b & $Z_{\text {Cond }}=516.62 \times A^{0.60}$ & {$[56]$} \\
\hline A3c & $Z_{\text {Cond }}=2143 \times A^{0.514}$ & {$[63]$} \\
\hline A3d & $Z_{\text {Cond }}=8500+406 \times A^{0.80}$ & {$[66]$} \\
\hline A3e & $Z_{\text {Cond }}=297 \times A$ & {$[67]$} \\
\hline A3f & $Z_{\text {Cond }}=1.56 \times 10^{5} \times(A / 200)^{0.89}$ & {$[53]$} \\
\hline A3g & $Z_{\text {Cond }}=2382.9 \times A^{0.68}$ & {$[51]$} \\
\hline A3h & $Z_{\text {Cond }}=516.621 \times A+268.45$ & {$[54]$} \\
\hline
\end{tabular}


Table A4. Pump purchasing cost equations.

\begin{tabular}{ccc}
\hline NO & Equation & References \\
\hline A4a & $Z_{p}=705.48 \times \dot{W}_{p}^{0.71}\left(1+\left(0.2 / 1-\eta_{p}\right)\right)$ & {$[73]$} \\
\hline A4b & $Z_{p}=2100 \times\left(\dot{W}_{p} / 10\right)^{0.26}\left(1-\eta_{p} / \eta_{p}\right)^{0.5}$ & {$[58,61]$} \\
\hline A4c & $Z_{p}=3540 \times \dot{W}_{p}^{0.71}$ & {$[55,74]$} \\
\hline A4d & $Z_{p}=200 \times \dot{W}_{p}{ }^{0.65}$ & {$[56,60,65]$} \\
\hline A4e & $Z_{p}=1120 \times \dot{W}_{p}{ }^{0.80}$ & {$[63,75]$} \\
\hline A4f & $Z_{p}=549.13 \times \dot{W}_{p}^{0.71} \times 1.41 \times\left(1+\left(0.2 / 1-\eta_{p}\right)\right)$ & {$[64]$} \\
\hline A4g & $Z_{p}=900 \times\left(\dot{W}_{p} / 300\right)^{0.25}$ & {$[67]$} \\
\hline A4h & $Z_{p}=500 \times\left(\dot{W}_{p} / 300\right)^{0.25}$ & {$[67]$} \\
\hline A4i & $Z_{p}=16,800 \times\left(\dot{W}_{p} / 200\right)^{0.67}$ & {$[76]$} \\
\hline A4j & $Z_{p}=1000 \times \dot{W}_{p}^{0.65}$ & {$[55]$} \\
\hline A4k & $Z_{p}=1785 \times\left(\dot{W}_{p} / 1000\right)^{0.71}\left(1+\left(0.2 / 1-\eta_{p}\right)\right)$ & {$[77]$} \\
\hline A41 & $Z_{p}=3500 \times \dot{W}_{p}^{0.41}$ & {$[58]$} \\
\hline A4m & $Z_{p}=9.84 \times 10^{3}\left(\dot{W}_{p} / 4000\right)^{0.55}$ & {$[57]$} \\
\hline A4n & $Z_{p}=3 \times 422 \times \dot{W}_{p}{ }^{0.71} \times 1.41 \times\left(1+\left(0.2 / 1-\eta_{p}\right)\right)$ &
\end{tabular}

\section{References}

1. Conti, J.; Holtberg, P.; Diefenderfer, J.; LaRose, A.; Turnure, J.T.; Westfall, L. International Energy Outlook 2016 with Projections to 2040; USDOE Energy Information Administration (EIA): Washington, DC, USA, 2016.

2. Borowski, P.F. Zonal and Nodal Models of Energy Market in European Union. Energies 2020, 13, 4182. [CrossRef]

3. Poyrazoglu, G. Determination of Price Zones during Transition from Uniform to Zonal Electricity Market: A Case Study for Turkey. Energies 2021, 14, 1014. [CrossRef]

4. Meps, M.I.L. Steel Prices Online. 2015. Available online: http://www.meps.co.uk/index-price.htm (accessed on 23 December 2015).

5. Tempesti, D.; Fiaschi, D. Thermo-economic assessment of a micro CHP system fuelled by geothermal and solar energy. Energy 2013, 58, 45-51. [CrossRef]

6. Thurairaja, K.; Wijewardane, A.; Ranasinghe, C. Thermo-Economic Analysis of Organic Rankine Cycle for Power Generation. In Proceedings of the 2018 IEEE 7th International Conference on Power and Energy (PECon), Kuala Lumpur, Malaysia, 3-4 December 2018; pp. 389-393.

7. Calise, F.; Cappiello, F.L.; Dentice d'Accadia, M.; Vicidomini, M. Thermo-economic analysis of hybrid solar-geothermal polygeneration plants in different configurations. Energies 2020, 13, 2391. [CrossRef]

8. Başoğul, Y. A parametric study on exergoeconomic analysis for a binary geothermal power plant with ORC. Int. J. Green Energy 2021, 1-12. [CrossRef]

9. Talluri, L.; Manfrida, G.; Fiaschi, D. Thermoelectric energy storage with geothermal heat integration-exergy and exergo-economic analysis. Energy Convers. Manag. 2019, 199, 111883. [CrossRef]

10. Shamoushaki, M.; Ghanatir, F.; Ehyaei, M.; Ahmadi, A. Exergy and exergoeconomic analysis and multi-objective optimisation of gas turbine power plant by evolutionary algorithms. Case study: Aliabad Katoul power plant. Int. J. Exergy 2017, 22, 279. [CrossRef]

11. Athari, H.; Soltani, S.; Rosen, M.A.; Mahmoudi, S.M.S.; Morosuk, T. Comparative Exergoeconomic Analyses of Gas Turbine Steam Injection Cycles with and without Fogging Inlet Cooling. Sustainability 2015, 7, 12236-12257. [CrossRef]

12. Shamoushaki, M.; Ehyaei, M.; Ghanatir, F. Exergy, economic and environmental analysis and multi-objective optimization of a SOFC-GT power plant. Energy 2017, 134, 515-531. [CrossRef]

13. Chitgar, N.; Emadi, M.A. Development and exergoeconomic evaluation of a SOFC-GT driven multi-generation system to supply residential demands: Electricity, fresh water and hydrogen. Int. J. Hydrogen Energy 2021. [CrossRef]

14. Tashtoush, B.; Megdouli, K.; Elakhdar, M.; Nehdi, E.; Kairouani, L. A Comprehensive Energy and Exergoeconomic Analysis of a Novel Transcritical Refrigeration Cycle. Processes 2020, 8, 758. [CrossRef] 
15. Schreve, K.; Schuster, H.R.; Basson, A.H. Manufacturing cost estimation during design of fabricated parts. Proc. Inst. Mech. Eng. Part B J. Eng. Manuf. 1999, 213, 731-735. [CrossRef]

16. Dean, E.P. Parametric cost deployment. In Proceedings of the Seventh Symposium on Quality Function Deployment, Novi, MI, USA, 11 June 1994; pp. 27-34.

17. Foussier, P.M.M. From Product Description to Cost: A Practical Approach: Volume 1: The Parametric Approach; Springer Science \& Business Media: Berlin/Heidelberg, Germany, 2006.

18. Williams, R. Six-tenths factor aids in approximating costs. Chem. Eng. 1947, 54, 124-125.

19. Pikukik, A.; Diaz, H.E. Cost estimating for major process equipment. Chem. Eng. 1977, 84, 106-122.

20. Purohit, G. Estimating costs of shell-and-tube heat exchangers. Chem. Eng. N.Y. 1983, 90, 56-67.

21. Vatavuk, W.M. A potpourri of equipment prices-Part 1. Chem. Eng. 1995, 102, 68.

22. Wang, W.-C. Simulation-Facilitated Model for Assessing Cost Correlations. Comput. Civ. Infrastruct. Eng. 2002, 17, 368-380. [CrossRef]

23. Loh, H.; Lyons, J.; White, C.W. Process Equipment Cost Estimation, Final Report; National Energy Technology Lab. (NETL): Morgantown, VA, USA, 2002.

24. Taal, M.; Bulatov, I.; Klemeš, J.; Stehlík, P. Cost estimation and energy price forecasts for economic evaluation of retrofit projects. Appl. Therm. Eng. 2003, 23, 1819-1835. [CrossRef]

25. Max, S.P.; Klaus, D.T.; Ronald, E.W. Plant Design and Economics for Chemical Engineers; McGraw-Hill Companies: New York, NY, USA, 2003.

26. Kim, G.-H.; An, S.-H.; Kang, K.-I. Comparison of construction cost estimating models based on regression analysis, neural networks, and case-based reasoning. Build. Environ. 2004, 39, 1235-1242. [CrossRef]

27. Yang, I.-T. Simulation-based estimation for correlated cost elements. Int. J. Proj. Manag. 2005, 23, 275-282. [CrossRef]

28. Turton, R.; Bailie, R.C.; Whiting, W.B.; Shaeiwitz, J.A. Analysis, Synthesis and Design of Chemical Processes; Pearson Education, Inc.: Hoboken, NJ, USA, 2008.

29. Caputo, A.C.; Pelagagge, P.M. Parametric and neural methods for cost estimation of process vessels. Int. J. Prod. Econ. 2008, 112, 934-954. [CrossRef]

30. Ogayar, B.; Vidal, P. Cost determination of the electro-mechanical equipment of a small hydro-power plant. Renew. Energy 2009, 34, 6-13. [CrossRef]

31. Kim, K.J.; Kim, K. Preliminary cost estimation model using case-based reasoning and genetic algorithms. J. Comput. Civ. Eng. 2010, 24, 499-505. [CrossRef]

32. Feng, Y.; Rangaiah, G.P. Evaluating capital cost estimation programs. Chem. Eng. 2011, 118, $22-29$.

33. Towler, G.; Sinnott, R. Chemical Engineering Design: Principles, Practice and Economics of Plant and Process Design; Elsevier: Amsterdam, The Netherlands, 2012.

34. Ereev, S.Y.; Patel, M.K. Standardized cost estimation for new technology (SCENT)-methodology and tool. J. Bus. Chem. 2012, 9, 31-48.

35. Gündüz, M.; Sahin, H.B. An Early Cost Estimation Model For Hydroelectric Power Plant Projects Using Neural Networks And Multiple Regression Analysis. J. Civ. Eng. Manag. 2015, 21, 470-477. [CrossRef]

36. Symister, O.J. An Analysis of Capital Cost Estimation Techniques for Chemical Processing. Ph.D. Thesis, Graduate School of Florida Institute of Technology, Melbourne, FL, USA, 2016.

37. Caputo, A.C.; Pelagagge, P.M.; Salini, P. Manufacturing cost model for heat exchangers optimization. Appl. Therm. Eng. 2016, 94, 513-533. [CrossRef]

38. Luyben, W.L. Capital cost of compressors for conceptual design. Chem. Eng. Process. Process. Intensif. 2018, 126, 206-209. [CrossRef]

39. Malhan, P.; Mittal, M. Evaluation of different statistical techniques for developing cost correlations of micro hydro power plants. Sustain. Energy Technol. Assess. 2021, 43, 100904. [CrossRef]

40. Shamoushaki, M.; Fiaschi, D.; Manfrida, G.; Niknam, P.H.; Talluri, L. Feasibility study and economic analysis of geothermal well drilling. Int. J. Environ. Stud. 2021, 1-15. [CrossRef]

41. Islam, M.S.; Nepal, M.P.; Skitmore, M.; Drogemuller, R. Risk induced contingency cost modeling for power plant projects. Autom. Constr. 2021, 123, 103519. [CrossRef]

42. IHS Inc. QUE\$TOR Petroleum Field Development and Production Cost Database, v. 2020 Q1: Englewood, Colo; IHS Inc.: London, UK, 2020.

43. Andrei, H.; Ivanovici, T.; Predusca, G.; Diaconu, E.; Andrei, P. Curve fitting method for modeling and analysis of photovoltaic cells characteristics. In Proceedings of the 2012 IEEE International Conference on Automation, Quality and Testing, Robotics, Cluj-Napoca, Romania, 24-27 May 2012; pp. 307-312.

44. Borowski, P. Innovative Processes in Managing an Enterprise from the Energy and Food Sector in the Era of Industry 4.0. Processes 2021, 9, 381. [CrossRef]

45. Niknam, P.H.; Talluri, L.; Fiaschi, D.; Manfrida, G. Improved Solubility Model for Pure Gas and Binary $\mathrm{Mixture}$ of $\mathrm{CO}_{2}-\mathrm{H}_{2} \mathrm{~S}$ in Water: A Geothermal Case Study with Total Reinjection. Energies 2020, 13, 2883. [CrossRef]

46. Niknam, P.H.; Fiaschi, D.; Mortaheb, H.; Mokhtarani, B. An improved formulation for speed of sound in two-phase systems and development of 1D model for supersonic nozzle. Fluid Phase Equilib. 2017, 446, 18-27. [CrossRef] 
47. Drachal, K.; Pawłowski, M. A Review of the Applications of Genetic Algorithms to Forecasting Prices of Commodities. Economies 2021, 9, 6. [CrossRef]

48. Matches' Equipment Cost Estimates. Available online: http://www.matche.com/equipcost/Default.html (accessed on 15 December 2020).

49. Available online: http://www.mhhe.com/engcs/chemical/peters/data/ce.html (accessed on 25 December 2020).

50. EdrawSoft. Available online: https://www.edrawmax.com/templates/ (accessed on 17 April 2021).

51. Rezayan, O.; Behbahaninia, A. Thermoeconomic optimization and exergy analysis of $\mathrm{CO} 2 / \mathrm{NH} 3$ cascade refrigeration systems. Energy 2011, 36, 888-895. [CrossRef]

52. Aminyavari, M.; Najafi, B.; Shirazi, A.; Rinaldi, F. Exergetic, economic and environmental (3E) analyses, and multi-objective optimization of a CO2/NH3 cascade refrigeration system. Appl. Therm. Eng. 2014, 65, 42-50. [CrossRef]

53. Smith, R. Chemical Process: Design and Integration; John Wiley \& Sons: Hoboken, NJ, USA, 2005.

54. Reyhani, H.A.; Meratizaman, M.; Ebrahimi, A.; Pourali, O.; Amidpour, M. Thermodynamic and economic optimization of SOFC-GT and its cogeneration opportunities using generated syngas from heavy fuel oil gasification. Energy 2016, 107, 141-164. [CrossRef]

55. Behzadi, A.; Gholamian, E.; Ahmadi, P.; Habibollahzade, A.; Ashjaee, M. Energy, exergy and exergoeconomic (3E) analyses and multi-objective optimization of a solar and geothermal based integrated energy system. Appl. Therm. Eng. 2018, 143, 1011-1022. [CrossRef]

56. Behzadi, A.; Gholamian, E.; Houshfar, E.; Habibollahzade, A. Multi-objective optimization and exergoeconomic analysis of waste heat recovery from Tehran's waste-to-energy plant integrated with an ORC unit. Energy 2018, 160, 1055-1068. [CrossRef]

57. Chitsaz, A.; Mehr, A.; Mahmoudi, S. Exergoeconomic analysis of a trigeneration system driven by a solid oxide fuel cell. Energy Convers. Manag. 2015, 106, 921-931. [CrossRef]

58. Sadeghi, M.; Chitsaz, A.; Mahmoudi, S.; Rosen, M.A. Thermoeconomic optimization using an evolutionary algorithm of a trigeneration system driven by a solid oxide fuel cell. Energy 2015, 89, 191-204. [CrossRef]

59. Parikhani, T.; Azariyan, H.; Behrad, R.; Ghaebi, H.; Jannatkhah, J. Thermodynamic and thermoeconomic analysis of a novel ammonia-water mixture combined cooling, heating, and power (CCHP) cycle. Renew. Energy 2020, 145, 1158-1175. [CrossRef]

60. Zare, V. A comparative exergoeconomic analysis of different ORC configurations for binary geothermal power plants. Energy Convers. Manag. 2015, 105, 127-138. [CrossRef]

61. Khani, L.; Mahmoudi, S.M.S.; Chitsaz, A.; Rosen, M.A. Energy and exergoeconomic evaluation of a new power/cooling cogeneration system based on a solid oxide fuel cell. Energy 2016, 94, 64-77. [CrossRef]

62. Marandi, S.; Mohammadkhani, F.; Yari, M. An efficient auxiliary power generation system for exploiting hydrogen boil-off gas (BOG) cold exergy based on PEM fuel cell and two-stage ORC: Thermodynamic and exergoeconomic viewpoints. Energy Convers. Manag. 2019, 195, 502-518. [CrossRef]

63. Wang, X.; Dai, Y. Exergoeconomic analysis of utilizing the transcritical CO2 cycle and the ORC for a recompression supercritical CO2 cycle waste heat recovery: A comparative study. Appl. Energy 2016, 170, 193-207. [CrossRef]

64. Mohammadi, A.; Ashouri, M.; Ahmadi, M.H.; Bidi, M.; Sadeghzadeh, M.; Ming, T. Thermoeconomic analysis and multiobjective optimization of a combined gas turbine, steam, and organic Rankine cycle. Energy Sci. Eng. 2018, 6, 506-522. [CrossRef]

65. Akrami, E.; Chitsaz, A.; Nami, H.; Mahmoudi, S. Energetic and exergoeconomic assessment of a multi-generation energy system based on indirect use of geothermal energy. Energy 2017, 124, 625-639. [CrossRef]

66. Khosravi, H.; Salehi, G.R.; Azad, M.T. Design of structure and optimization of organic Rankine cycle for heat recovery from gas turbine: The use of 4E, advanced exergy and advanced exergoeconomic analysis. Appl. Therm. Eng. 2019, 147, 272-290. [CrossRef]

67. Lecompte, S.; Huisseune, H.; Van den Broek, M.; De Schampheleire, S.; De Paepe, M. Part load based thermo-economic optimization of the Organic Rankine Cycle (ORC) applied to a combined heat and power (CHP) system. Appl. Energy 2013, 111, 871-881. [CrossRef]

68. Zoghi, M.; Habibi, H.; Chitsaz, A.; Javaherdeh, K.; Ayazpour, M. Exergoeconomic analysis of a novel trigeneration system based on organic quadrilateral cycle integrated with cascade absorption-compression system for waste heat recovery. Energy Convers. Manag. 2019, 198, 111818. [CrossRef]

69. Mohammadkhani, F.; Yari, M. A 0D model for diesel engine simulation and employing a transcritical dual loop Organic Rankine Cycle (ORC) for waste heat recovery from its exhaust and coolant: Thermodynamic and economic analysis. Appl. Therm. Eng. 2019, 150, 329-347. [CrossRef]

70. Gholizadeh, T.; Vajdi, M.; Mohammadkhani, F. Thermodynamic and thermoeconomic analysis of basic and modified power generation systems fueled by biogas. Energy Convers. Manag. 2019, 181, 463-475. [CrossRef]

71. Mosaffa, A.; Farshi, L.G.; Ferreira, C.I.; Rosen, M. Exergoeconomic and environmental analyses of CO2/NH3 cascade refrigeration systems equipped with different types of flash tank intercoolers. Energy Convers. Manag. 2016, 117, 442-453. [CrossRef]

72. Hall, S.; Ahmad, S.; Smith, R. Capital cost targets for heat exchanger networks comprising mixed materials of construction, pressure ratings and exchanger types. Comput. Chem. Eng. 1990, 14, 319-335. [CrossRef]

73. Soltani, S.; Mahmoudi, S.; Yari, M.; Morosuk, T.; Rosen, M.; Zare, V. A comparative exergoeconomic analysis of two biomass and co-firing combined power plants. Energy Convers. Manag. 2013, 76, 83-91. [CrossRef]

74. Shokati, N.; Ranjbar, F; Yari, M. Comparative and parametric study of double flash and single flash/ORC combined cycles based on exergoeconomic criteria. Appl. Therm. Eng. 2015, 91, 479-495. [CrossRef] 
75. Bina, S.M.; Jalilinasrabady, S.; Fujii, H. Thermo-economic evaluation of various bottoming ORCs for geothermal power plant, determination of optimum cycle for Sabalan power plant exhaust. Geothermics 2017, 70, 181-191. [CrossRef]

76. Ghasemian, E.; Ehyaei, M.A. Evaluation and optimization of organic Rankine cycle (ORC) with algorithms NSGA-II, MOPSO, and MOEA for eight coolant fluids. Int. J. Energy Environ. Eng. 2017, 9, 39-57. [CrossRef]

77. Haghghi, M.A.; Shamsaiee, M.; Holagh, S.G.; Chitsaz, A.; Rosen, M.A. Thermodynamic, exergoeconomic, and environmental evaluation of a new multi-generation system driven by a molten carbonate fuel cell for production of cooling, heating, electricity, and freshwater. Energy Convers. Manag. 2019, 199, 112040. [CrossRef]

78. Jahangir, M.H.; Mousavi, S.A.; Rad, M.A.V. A techno-economic comparison of a photovoltaic/thermal organic Rankine cycle with several renewable hybrid systems for a residential area in Rayen, Iran. Energy Convers. Manag. 2019, 195, 244-261. [CrossRef] 